\title{
Article
}

\section{A critical assessment of the impact of the 2000 equality directives on Greece}

\author{
Alkiviadou, Natalie \\ Available at http://clok.uclan.ac.uk/21364/ \\ Alkiviadou, Natalie ORCID: 0000-0002-4159-8710 (2017) A critical assessment \\ of the impact of the 2000 equality directives on Greece. International Journal \\ of Discrimination and the Law, 17 (4). pp. 220-238. ISSN 1358-2291
}

It is advisable to refer to the publisher's version if you intend to cite from the work. http://dx.doi.org/10.1177/1358229117745717

For more information about UCLan's research in this area go to

http://www.uclan.ac.uk/researchgroups/ and search for < name of research Group>.

For information about Research generally at UCLan please go to http://www.uclan.ac.uk/research/

All outputs in CLoK are protected by Intellectual Property Rights law, including Copyright law. Copyright, IPR and Moral Rights for the works on this site are retained by the individual authors and/or other copyright owners. Terms and conditions for use of this material are defined in the policies page.

\section{CLoK}

Central Lancashire online Knowledge www.clok.uclan.ac.uk

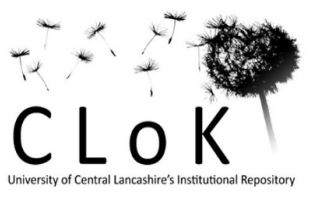


A critical assessment of the impact of the 2000 equality directives on Greece

Natalie Alkiviadou

School of Law, University of Central Lancashire Cyprus, Pyla, Larnaka, Cyprus Corresponding author: Natalie Alkiviadou, School of Law, University of Central Lancashire Cyprus, University Ave 12-14, Pyla 7080, Larnaka, Cyprus. Email: nalkiviadou@uclan.ac.uk International Journal of Discrimination and the Law 2017, Vol. 17(4) 220-238 a The Author(s) 2017 Reprints and permission: sagepub.co.uk/journalsPermissions.nav DOI: 10.1177/1358229117745717 journals.sagepub.com/home/jdi

\begin{abstract}
Greece transposed the 2000 equality directives through Law 3304/2005. This law sets out the definitions of direct and indirect discrimination, designates what conduct should be prohibited, outlines the sanctions that are to be imposed by the judiciary and mandates three equality bodies with the duty of upholding and promoting equal treatment. This article argues that notwithstanding the theoretical significance of this law given that it was the first tool specifically designed to grant legislative protection for the principle of equal treatment, its practical effects are limited.
\end{abstract}

Keywords non-discrimination, Council Directive 2000/78/EC, Council Directive 2000/43/EC, Greece 


\section{Introduction}

The European anti-discrimination framework took a great leap forward with the incorporation of Article 19 of the Treaty on the Functioning of the European Union and the subsequent adoption of Council Directives 2000/43/EC1 (hereinafter the Racial Equality Directive) and 2000/78/EC2 (hereinafter the Employment Equality Directive), which aim to tackle racial discrimination and provide a general framework for equal treatment in the workplace, respectively. This was a significant development for the European legal reality, which 'altered the character of EU anti-discrimination law's as it designated race and ethnicity, religion, sexual orientation, disability and age as characteristics to be protected from discrimination. Ironically, the directives, which seek to promote equal treatment, endorse a hierarchy of protected characteristics and their interrelated equality. The Racial Equality Directive encompasses equal treatment in relation to employment, vocational training, social protection and advantages, education and access to and supply of goods and services.4 The Employment Equality Directive, which integrates the rest of the protected characteristics, such as disability and age, is limited to the workplace. 5 This distinction has led to the 2000 directives carrying 'an aura of unfinished business',6 with no convincing explanation having yet been put forth for this difference.7 In 2008, the Council of the European Union made a proposal to rectify this imbalance, 8 which has been met with resistance by some Member States.9 Undoubtedly, the differences between the directives, especially when taking into account their purpose, taint the quality and efficacy of any national law that transposes the directives as they stand. Nearly 20 years, following the adoption of the directives, is a suitable time to consider their actual effects vis-a-vis the promotion of equal treatment in Member States, since all countries have transposed them, national judicial and nonjudicial bodies have had some time to deal with the issues tackled therein and the European Court of Justice has contributed to the understanding of the principles and notions they entail. To provide a specific assessment of the directives' effects, this article opts to consider their transposition into the domestic law of a Member State, which was lacking any coherent legal infrastructure for the promotion of equal treatment in the era before the directives.10 The chosen case study is Greece. Today, the promotion of equal treatment and non-discrimination in Greece is accommodated in Law 3304/2005 on the implementation of the principle of equal treatment irrespective of racial or ethnic origin, religion or other beliefs, disability, age or sexual orientation. This 'law fills a conspicuous lacuna in the Greek legal system, where there was previously no specific anti-discrimination legislation in force', 11 a point which demonstrates the significant effect of the directives, at least on a theoretical level. To ascertain the precise impact of the two directives on this Member State, this article will examine the pre-2005 legal framework, provide a general overview and critique of Law 3304/2005 and examine how, and the extent to which, the relevant law is enforced by judicial and nonjudicial bodies. The overarching aim of this examination is to establish whether the 2000 European developments have, in fact, contributed to the creation of a functioning non-discrimination framework in the country under consideration. Legal framework before the transposition of the 2000 equality directives The Greek constitution contains several provisions relevant to non-discrimination and equal treatment and the particular purposes of the two directives. For example, Article 5.2 stipulates that all persons living within Greek territory, and not just Greek citizens, shall enjoy the full protection of their life, honour and liberty irrespective of nationality, race or language and religious or political beliefs, while Article 5.5 provides that all 221 persons have the right to the protection of their health and of their genetic identity. In theory, these provisions provide for constitutional 
protection against non-discrimination in some spheres in the event that no other relevant legislation exists.12 However, their abstract nature and limited scope meant that, prior to the passing of Law 3304/2005, persons were essentially deprived of legal protection if they fell victim to the discrimination of the type provided for in the directives, since it was and continues to be 'extremely difficult to derive specific enforceable rights form these general principles'.13 Other mechanisms within the broader non-discrimination framework include the Civil Code, which contains generalized clauses relevant to the claims of discrimination in the workplace, ones which are rarely pursued when dealing with the protected characteristics of the directives.14 In fact, the only piece of legislation which specifically addressed the issue of equality that existed pre-2005 was in the sphere of gender equality.15 Thus, combatting discrimination on the five grounds set out by the directives in the workplace and/or other areas, such as social protection, was not protected by a specialized statute. Here, it must be noted that, as well as the significant developments brought about by the equal treatment law, the 2001 constitutional revisions, and particularly, the incorporation of Article 25 in the constitution, were significant to the protection of equal treatment in the private domain. More particularly, this article obliges the State to ensure the unhindered and effective exercise of human rights, extending this obligation to relations between individuals and not just vis-à-vis the State. This laid down the foundations for the subsequent duties which were to be imposed in 2005 on persons acting in a discriminatory manner in the private sphere, such as a private employer to an employee. In theory, as a result of the new legal framework created in 2005, Greece has been described as possessing 'a well-rounded protection framework in the field of discrimination'.16 The extent to which this is completely accurate will be elaborated further, with this article arguing that the current domestic legislation is marked by some central limitations which hinder its effective application and that the law is not effectively used as a mechanism of prevention, protection, punishment and/or redress. Furthermore, when looking beyond the contents of the directives which are limited to certain areas, such as employment, that have been almost arbitrarily designated as protected areas, the fact remains that, even post2005, persons continue to be deprived of any kind of legal protection from discrimination that may occur outside the boundaries set out by the law under consideration which limits itself to the provisions of the two directives. The same can be said for the protected characteristics, which are limited to race and ethnicity, religion or belief, sexual orientation, disability and age.

\section{Overview of law 3304/2005 that transposed the 2000 equality directives Transposition process}

As with many other Member States, the transposition procedure of the Racial Equality Directive in Greece did not run smoothly. In 2004, the European Commission instigated infringement proceedings against several countries, including Greece, due to their noncompliance with the Racial Equality Directive.17 Proceedings against Greece ceased due to the passing of the transposing law in 200518 Law 3304/2005 transposes the two equality directives, thereby covering the principle of equal treatment in relation to the five established grounds in the areas designated by the directives. Article 1 of the law notes that its purpose is to lay down a general regulatory framework for combating discrimination on the grounds of racial or ethnic origin, as well as combating discrimination on the grounds of religion or other beliefs, disability, age or sexual orientation in the spheres of occupation and employment, according to Directives 2000/43/EC ... . and 2000/78/EC so as to guarantee the principle of equal treatment. 
However, it is evident that the Greek legislature did not intend to provide specific regulations with regard to the implementation of the principle of equal treatment, but a general framework.19

\section{Definitional framework}

The law sets out two identical definitions for direct and indirect discrimination, one relating to the grounds laid down by the Racial Equality Directive20 and one to those of the Employment Equality Directive, 21 both of which comply with the provisions of the directives. In relation to the grounds of discrimination, the European Commission against Racism and Intolerance 22 (hereinafter ECRI) has suggested that this law is extended so as to incorporate discrimination based on colour, language and citizenship, thereby, allowing for a broader anti-discrimination framework.23 Law 3304/2005 is the first piece of legislation to have defined harassment 24 based on the directives and to have incorporated it as a specific offence. 25 However, the law does not specifically define what is meant by the types of discrimination included therein and, interrelated to this, Law 3304/2004 does not define grounds such as race or religious belief. Although not directly required by the relevant directives, given that such definitions are generally absent from Greek legislation,26 an extrapolation on meanings of, inter alia, race and racial discrimination would allow for clarification of semantics and notions that would facilitate the tasks set out for enforcement bodies. Judicial and administrative bodies have no guidelines as to which groups are actually protected by this law, since intricate questions as to what may constitute a belief and whether a particular non-mainstream religion is deemed as such by the State are left unanswered. Given the centricity of the discrimination grounds to the subsequent application of the law, it could have been expected that some sort of definitional framework would have been applied. Furthermore, there is no relevant case law on the tests which must be applied and satisfied in order to meet the threshold of prohibited conduct and to justify the legitimate aims of permitting discrimination.27 Such legitimate aims include the more general ones of protecting, inter alia, public security and the rights and freedoms of others in relation to the provisions of Directive 2000/78/EC28 as well as more particular issues, such as genuine and determining occupational requirements, which have not yet been defined and interpreted by the courts. In addition, since the legislation is as general as it is, endorsing only the minimum requirements set out by the directives, and taking into account the lack of jurisprudential analysis by national courts, there is no indication as to whether the country's legal framework embraces principles such as the prohibition of discrimination or harassment by association, as set out in the European Court of Justice's judgment in Coleman.29 Furthermore, there are no provisions in Law 3304/2005 or related case law that place a direct obligation on public authorities to prevent discrimination in carrying out their functions, something which ECRI recommends,30 nor is there anything relevant vis-a -vis multiple discrimination.31 The latter issue has been partly rectified by Article 2.1 of the Law 3996/2011 on the reform of the Labour Inspectorate Body, discussed below, which holds that this body, among others, takes into account instances of multiple discrimination, in accordance with Article 19 of Law 3304/2005, which sets out its duties within the equal treatment framework.

\section{Restrictive scope vis-à-vis discrimination based on non-racial grounds}

Law 3304/2005 provides a mirror image of the directives à propos the scope of protection provided. Chapter II of the law, which incorporates Directive 2000/43/EC, extends the prohibition of discrimination to occupation, membership of an association of workers or 
employers, vocational training, social protection, social advantages, education and access to and supply of goods and services. Chapter III, which incorporates Directive 2000/78/EC, limits its scope to employment, membership of an association of workers or employers and vocational training. Although the law is implementing the provisions of the directives, as noted above, this aspect of the provisions is marred by inequality, given that the provisions on racial discrimination granted a wider scope. In this light, ECRI has, on several occasions, recommended that this statute should be amended to ensure the same scope in relation to both chapters and, thus, both directives, but no amendments have been made to date. 32

\section{Limitations regarding citizenship and residency requirements}

Law 3304/2005 implements Article 3(2) of both directives and does not, thereby, cover differences of treatment based on nationality and is without prejudice to the entry and residence of third-country nationals and stateless persons and to any treatment which arises from the legal status of such persons. Although this provision is directly provided for by the directives, its negative effects must not be ignored given that, as noted, it 'essentially constitutes a complete justification of any direct or indirect discrimination against migrants due to their non-Greek citizenship'.33 The Ombudsperson has noted that ousting third-country nationals from the law results in the fact that 'the administration is often facing the rights of non-Greek citizens with reserve'.34 In fact, the Ombudsperson argued that this attitude also extends to EU citizens and naturalized Greeks, 35 and, to this end, recommended that, at least in the case of long-term third country residents or vis-a -vis cases of serious racial discrimination, the directives should be applicable. 36

\section{Sanctions and victims' redress}

In the event that the principle of equal treatment is violated in the framework of an administrative action, the victim may commence judicial proceedings with court judgments, providing several sanctions and/or forms of redress. For discriminatory administrative actions, the law provides, inter alia, redress of the material or moral harm through the cancellation or the amendment of the action in question.37 Discriminatory actions during the provision of goods and services on the grounds of racial or ethnic origin, religious or other beliefs, disability, age or sexual orientation come with criminal penalties, with Article 16 of Law 3004/2005 foreseeing a prison sentence and a monetary fine for such cases.38 In the realm of occupation and employment, an employer who violates the principle of equal treatment is considered to be in violation of Greek Labour Law, and particularly Article 16 of Law 2639/1998, which sets out an administrative sanction, namely a monetary fine 39 and a temporary or permanent cessation of business activities. Two points can be discerned from the above, firstly that, although the provision of goods and services is not within the scope of Chapter III which deals with discrimination on the grounds set out in Directive 2000/78/EC including, inter alia, disability, the same law does provide for sanctions in the event that discrimination on such grounds occurs during the provision of goods and services. This demonstrates incoherence in the law, with restrictive conditions in the sphere of the general provisions regarding Directive 2000/78/EC and more extensive provisions in the sanctioning process. Secondly, the above reflects that Law 3004/2005 is wanting in respect of effective redress of victims of discrimination and sanctioning of perpetrators in the field of the supply of goods and services and employment and occupation, given that the punishments provided for include fines payable 
to the State, prison sentences and/or cessation of business activities rather than monetary compensation or other means of restitution or redress for the victim, as is the case with administrative actions, which violate the principle of equal treatment. In addition, no monetary compensation is provided for in relation to administrative actions, which may result in a breach of the law. If a victim opts to seek redress through an equality body rather than through the courts, the only body with more extended sanctioning powers is the Labour Inspectorate Department, which may, for example, order the interruption of business, impose administrative measures and sanctions and commence judicial proceedings. 40 However, the aforementioned department functions only in the realm of private employment and occupation.41 As a result of the above, although Article 15 of the Racial Equality Directive and Article 17 of the Equal Treatment Directive only provide that sanctions may involve payments to the victim, the sanctions applied in Greece, minus the more extensive measures of redress in the framework of discriminatory administrative actions, result in the current law failing to provide for effective sanctions and/or restitution for harmful conduct.

\section{Practical impact of the 2005 legal framework}

\section{Added value of the law}

Law 3304/2005 provides the first 'complete institutional framework of protection' 42 in the realm of equal treatment, albeit one marked by generality. For the first time, Greece has legislation, which clarifies the meaning of discrimination, direct and indirect, defines harassment, makes it a specific offence and incorporates it in the field of nondiscrimination and provides protection to victims of discrimination in the designated spheres by judicial and nonjudicial means, with the former extending to criminal as well as civil law.43 In relation to victims, the role of the equality bodies in the field of equal treatment theoretically provides vulnerable groups, who may experience poverty and social exclusion, with the opportunity to seek a nonjudicial path of redress which is not burdensome in terms of cost and efficiency.44As well as working towards the punishment of perpetrators, the law addresses the issue of prevention, inter alia, providing that the Economic and Social Council 45 should work towards the implementation of measures on a national and local level for the promotion of the purposes of the law.46 It can generally be said that the transposing law is in line with the two directives and is 'wide in scope and reflects international and European standards on protection against racial discrimination'.47

\section{Shortcomings in the use and enforcement of Law 3004/2005}

Notwithstanding the added theoretical value of the 2005 law, its practical impact can be disputed as illustrated by four distinct yet interrelated issues. Firstly, there are a limited number of cases reaching the courts predominantly, because victims of discrimination are not actively and systematically seeking redress in courts, while the amount of case law is stifled by the limited role entities such as NGOs and Trade Unions have in instigating proceedings. Secondly, although no concrete patterns can be discerned from the case law, due to the lack of it, the few examples that do exist reveal certain issues such as the tardiness of the judiciary in applying legislative provisions, its confusion with core principles of the law and the relatively insignificant position this law holds in the courts' books. In relation to the last point, as will be demonstrated below, there have been occasions when the courts have either simply referred to 
the law almost incidentally or have passed judgment on an issue that falls within its framework without any reference to the 2005 statute. This argument is notwithstanding some good but isolated examples of the law's use. Thirdly, the equality bodies, some more than others, have proved to function ineffectively, thereby, preventing the administrative enforcement of the law. Finally, there exist several day-to-day examples of discrimination occurring in Greece that could essentially be tackled by the legislation but continue to occur on a long-term and largescale basis.

Limited recourse to courts. There is a lack of relevant case law reaching the national courts. In fact, the use of the judicial route for the cases of discrimination has been minimal. The main problem faced by the victims of discrimination is the cost of instructing a lawyer.48 Article 13.3 of Law 3340/2005 provides that legal entities which aim at protecting the principle of equal treatment have the right to represent a victim before judicial or administrative proceedings as long as the victim's consent is provided.49 However, in reality, compliance with the directives when it comes to allowing legal entities to represent victims is curtailed, since this is not yet part of procedural codes.50

In addition to the above, inadequate recourse to the courts has also arisen due to the limited roles of legal entities, such as NGOs and Trade Unions, in instigating the proceedings for cases that do not have specifically identified and consenting victims. This is in line with Article 7.2 of the Racial Equality Directive and Article 9.2 of the Employment Equality Directive, which provide for such representation with the victim's approval. However, the ECRI recommended an amendment to Law 3304/2005 in order to allow entities, such as NGOs, to instigate court proceedings in the area of equal treatment without having to represent a specific victim.51 Such an amendment would allow for a more extensive application of the law but no measures to this end have yet been taken by the State. An example to illustrate the shortcomings of this provision is the case of Muslim teachers who have been banned from teaching the Greek language in Thrace.52 In 2014, an amendment to a law was passed53 which provided that members of the Muslim minority in Thrace are no longer to be recruited for teaching in the Greek language programme of minority primary schools.54 This new provision is inconsistent with Law 3004/2005, but steps have yet to be taken, since no victim has yet commenced judicial proceedings. This reflects the shortcomings of the current status vis-a'-vis legal entities having to represent identifiable and consenting victims before instigating judicial proceedings.

In the realm of unidentified and consenting victims, an interesting case is one in which a Greek doctor and member of Golden Dawn posted a 'Jews not Welcome' sign outside his office and was subsequently arrested for inciting racial discrimination, in violation of anti-racist Law 972/1979.55 This incident falls within the framework of Law 3004/2005 as the doctor, through his sign, ousted an entire ethnic and/or religious group from the provision of his services. However, the prosecutor had to pursue this case in the realm of Law 972/1979 'due to the lack of an identified victim of discrimination'.56 Therefore, since NGOs cannot bring cases before judicial bodies without a designated victim under the anti-discrimination law, the only path available in the realm of ethnic and racial discrimination is the anti-racist law. Section 3 of the anti-racist law penalizes the act of refusing, in the exercise of one's occupation, to sell a commodity or to supply a service on racial or ethnic grounds. Thus, while there exists another option in the framework of the supply of goods and services for persons discriminated against due to their race or ethnicity, even if no consenting victim is identified for purposes of a trial, no such alternative is available for the other groups protected by equal treatment legislation. 
So, as is the case with the limitations regarding citizenship and residency, the necessity of a consenting victim is a direct result of the provisions of the directives and not a deviation by the State from its European obligations. Either way, such characteristics of the law are considered by institutions, such as the ECRI, to constitute shortcomings that directly affect the practical applicability and scope of the equal treatment framework of Member States which choose to apply the directives' provisions as minimally as possible.

Judicial enforcement of Law 3304/2005. This section will attempt to consider the effect of the law on the Greek judicial scene. To do so, it will look at whether and, if so, to what extent, national courts have taken the 2005 law into account and whether, and to what extent, the law has brought something new to the country's legal framework. It must be noted that there is a lack of available statistics for the number of discrimination cases brought to justice, 57 which may hamper this task.

In 2015, a national court58 declared unconstitutional the State reduction of the minimum wage for employees under the age of 25 by $32 \% 590$ on the grounds that this constituted discrimination. In its decision, the court referred to the relevant constitutional provisions, such as the right of equality before the law and equal pay,60 and then it referred to the general principle of equal treatment under European and international law, subsequently making reference to Law $3004 / 2005$. However, it made no extrapolation or discussion of the provisions found, therein, and simply referred to that law as it did to Law 1424/1984 which incorporates the international convention concerning discrimination in respect of employment and occupation.

In 2003, a woman initiated judicial proceeding before the administrative courts on the grounds of age discrimination, since she had been denied access to the profession of bailiff for the reason that she had already turned 35 years old.61 The final decision was issued with a 9-year delay in 2012 by the Greek Council of State, which found that the impugned measure was unconstitutional. In its decision, the court held that preventing persons from this employment on the grounds of age was unnecessary, since the performance of such a position did not entail any biological needs for the person to be under 35 years old and that the measure breached the principle of proportionality and occupational freedom as provided for in the constitution. Thus, rather than relying on the prohibition of age discrimination as so provided in Law 3004/2005, which existed at the time of the judgment's passing, the court opted to rely on the constitution.62

In 2011, the Deputy Prosecutor of the Greek Supreme Court received a letter from the association named Coordinated Organisations and Communities for Roma Human Rights in Greece, which requested the investigation of the cases of exclusion of Roma children in the national education system. In response to this, the Deputy Prosecutor issued an Urgent Written Order63 addressed to all local prosecutors of Greece officially requesting that they 'take care to strike out the phenomenon of exclusion of Roma from the public educational system' 64 and that their 'integration to all structures of the State should be ensured'.65 Notwithstanding the significance of this in relation to the development of the anti-discrimination framework in Greece, the fact remains that the Order did not directly refer to the provisions of Law $3004 / 2005$.

The first case demonstrates the almost incidental reference to the 2005 law whil the others make absolutely no reference to it at all. This could demonstrate that antidiscrimination initiatives can, in fact, stand well, even on a judicial level, without reliance on Law 3004/2005. It also reveals, to the extent possible given the limited available jurisprudence that may be 
assessed, the minimal practical effect this law has in this Member State. However, in relation to the 2011 case, it has been argued that 'there is no doubt that at least this concrete judicial authority has fully realised the tremendous importance of the enforcement of the existing legal framework against discrimination'.66 This argument supports the position that the 2005 law has influenced judicial decisions in relation to the non-discrimination framework on an abstract level. Nevertheless, even if this is the case, the impact of the 2005 law continues to be insufficient given that more than 10 years have passed since the adoption of the 2005 law and, therefore, more tangible results should have come about.

As well as non-reliance or partial reliance on the 2005 law, there are other limitations to the law's enforcement by the courts, namely the slow pace of enforcement and the judicial confusion on key themes. In 2013, a bus driver of a transport company of the city of Thessaloniki forced two passengers of African descent to get off the bus for no apparent reason. When the other passengers criticized this behaviour, the driver declared that he was a Golden Dawn supporter.67 An association, the Nazi-Free Thessaloniki Assembly, filed a complaint to the Organization of Public Transportation of Thessaloniki. The case resulted in the intervention of the Misdemeanours Prosecutor of Thessaloniki who ordered a preliminary inquiry into the case. The court found the perpetrator guilty of denying access to services on racial grounds, holding that the bus driver's conduct offended the victims' dignity and created an intimidating, humiliating or offensive environment, without, however, referring to the term 'harassment'.68 It ordered his 10-month imprisonment suspended for 3 years and a fine of EUR 1000.69 This was the first time that Article 16, which provides for criminal penalties for discriminatory behaviour in the supply of goods and services, was enforced, reflecting a 9-year delay since the law's creation.70

In 2008, the judiciary demonstrated confusion in relation to a core principle of the law, namely that of reasonable accommodation. First, it must be noted that Article 10 of the 2005 law transposes Article 5 of the Employment Equality Directive word for word into national law. In the case under consideration, the Athens Court of First Instance found that a disabled bank officer had been discriminated against under Law 3004/2005 given that she had been transferred to another branch which was far from her home and, thus, harder for her to access.71 In reaching this decision, the court first checked whether other employees were available to work at that bank branch. It has been argued that the court seemed to have become confused in relation to the duty of reasonable accommodation since, even in the event that no other suitable employees existed in the other branch, this would not have resulted in a finding against the employee since 'the duty to provide reasonable accommodation is very strict and favours persons with disabilities'.72

Thus, nearly 20 years since the directives and over 10 years since the passing of the transposing law, the judicial enforcement of the law can be summed up as minimal in quantity and in quality. In relation to the first point, the fact remains that victims are simply not seeking redress in the courts under this law with other entities unable to bring forth cases without identified and consenting victims. In relation to the issue of quality, relevant cases have shown slowness in applying principles of the law, confusion on its provisions and, significantly, a lack of or no reliance on Law 3004/2005 when faced with non-discrimination cases.

Equality bodies: Contributing to the ineffectiveness of the law's enforcement. 
Article 13 of the Racial Equality Directive provides for the designation of a body or bodies to assist victims in pursuing discrimination claims, conduct surveys, publish reports and make recommendations in an independent manner, within the realm of non-discrimination. In Greece, three such bodies have been mandated to function within the framework of Article 13, these being the Ombudsperson, the Committee for Equal Treatment and the Labour Inspectorate Body.

The Ombudsperson is an independent authority created following the 2001 constitutional revisions and is set out as one of the equality bodies under Law 3304/2005. The 2005 law amends Law 3094/2003, which established the Ombudsperson, extending its mandate to include the protection of the rights and interests of the child and the promotion of the principle of equal treatment of all persons with no distinction as to racial or ethnic group, religious or other beliefs, age, disability or sexual orientation.73 The Ombudsperson's powers are incorporated in the 2003 law, which charges this institution with the duty of investigating relevant cases following the submittal of a complaint, 74 instigating investigations on its own initiative 75 and making recommendations to the relevant authority on the steps that need to be taken for the case to be resolved.76 The Ombudsperson is granted the duty of conducting research and publishing special reports on the promotion and protection of the principle of equal treatment vis-a -vis the groups dealt with by the directives.77 Taking into account that the need for an equality body is provided for only by the Racial Equality Directive and, thus, only in the sphere of race and ethnicity, it must be underlined that Greece opted to move beyond the scope of the directives, since it mandated the Ombudsperson with duties to tackle discrimination against all five protected grounds, rather than solely within the framework of race and ethnicity. However, certain disadvantages can be pinpointed in relation to the functioning of the Ombudsperson. First, an injured party must submit a complaint within 6 months78 of a particular occurrence, a period which has been deemed too short.79 Second, in the event that a positive response is not received from an authority, the only power granted to the Ombudsperson is to publicize this occurrence, if it is considered that this is not sufficiently justified.80 Moreover, the more extensive powers pertain to the case's reference to a prosecutor in the event of a criminal act conducted by a public officials1 or, in the event of unlawful behaviour on the part of the public official, the relevant body for disciplinary action. 82 Furthermore, it must be noted that no reference is made in either law for incorporating the provision of independent assistance to the victims of discrimination in pursuing their complaints regarding discrimination, as provided for by Article 13(2) of the Racial Equality Directive.

During 2014, 216 cases were examined by the Ombudsperson in the field of discrimination with 77 having been carried over from the previous year. A violation was found in 56 of the total cases with 25 of those resulting in a positive approach adopted by the public authority in question.83 Among the cases brought forth before the Ombudsperson, there have been several good examples in the framework of anti-discrimination law. It is beyond the scope of this article to assess all the cases in detail so one example will be provided to demonstrate the effects of Law 3004/2005 on equal treatment in Greece. The Ombudsperson was informed about the establishment of an upper age limit of 40 years old for employment in the Greek Naval Chamber. The Ombudsperson intervened on his own initiative, advising the Greek Naval Chamber that this practice was discriminatory on the grounds of age, as so provided by Law 3304/2005. The Naval Chamber responded in a positive manner, removing the age 
requirements.84 To put it briefly, without the 2005 law and the powers it grants to the Ombudsperson to intervene in the cases of discrimination, this case would have had to go through the courts, with the victim or 17(4) victims relying on generalized constitutional provisions of equality and nondiscrimination.

As well as examining complaints and writing reports, the Ombudsperson has carried out other initiatives to contribute to the promotion of equal treatment, such as the publication of a Diversity Guide for public servants regarding the anti-discrimination legislation in addition to details and information thereof with the purpose of rendering them more sensitive to and aware of the rights and needs of possible victims of discrimination. 85 Thus, this body has taken a holistic approach to the promotion of equal treatment in Greece.

The Committee for Equal Treatment was established by Article 21 of the 2005 Law and is part of the Ministry of Justice. It is responsible for examining the violations of equal treatment by private persons, both natural and legal, functioning outside the fields of employment and occupation.86 It oversees the conciliatory process which is conducted by the interrelated Department on Equal Treatment 87 and must compose reports in the event that a conciliatory process fails. It may also issue opinions and reports about the interpretation and implementation of the law.88 However, this body has no powers to impose sanctions or fines. To date, no information is available on the number of complaints received by the Equal Treatment Committee nor are there any figures on the number of cases duly addressed and solved. 89 Furthermore, this body has yet to compose any reports on failed conciliatory procedures, as provided for by the law which established it. In addition, this body has, since its creation 'largely been inactive'.90 As well as its limited powers and authority, the affiliation with a Ministry has led the Economic and Social Councily1 to underline that this body should be made independent so as to comply with directive 2000/45/EC.92 This is because Article 13 of the Racial Equality Directive refers to the independence of assistance provided to victims and to the surveys and reports issued by equality bodies. The Economic and Social Council has noted that the Equal Treatment Committee needs an increase in human and other resources in order to allow it to function effectively93 and that its powers should extend to being able to impose penalties so as to punish and not only prevent discriminatory acts.94

In the framework of employment and occupation, it is the Labour Inspectorate Body of the Ministry of Labour, Social Security and Social Solidarity that is responsible for examining the incidents of a violation of the principle of equal treatment by private natural and legal persons. 95 This body uses conciliatory means but, unlike the other two bodies, has the authority to impose fines which are paid to the State96 in the event that a violation of the principle of equal treatment is determined. In its latest report of 2009, approved in 2011, the Economic and Social Council noted that the Labour Inspectorate Body had never, by that time, produced a report on equal treatment, since it had not dealt with any cases of a violation.97 In the Labour Inspectorate Body's latest report of 2013, the only reference to the law under consideration was a mention that the inspectors of labour relations advise employers and employees on the principle of equal treatment and seek to facilitate the access and participation of disabled persons in the workplace and in vocational training. 98 However, no details are provided on such actions whil no mention is made of cases pursued within the framework of the law. It has been argued that the inability of this department to function efficiently is, in part, a result of the lack of staff at its disposal.99 This position is illustrated by the case of the Manolada, where at least 28 migrant strawberry pickers were shot by the farmers for demanding owed wages.100 Following the shootings, the 
General Confederation of Greek workers101 criticized the Labour Inspectorate for failing properly to investigate working conditions for migrants in Manolada, which it likened to modern slavery.102 'The criminal act in Manolada shows the tragic results of labour exploitation, combined with a lack of control by the governmental Labour Inspectorate Body'.103 Furthermore, the Ombudsperson issued a report on the need for the immediate, coordinated and effective intervention of the State in relation to the working conditions of the strawberry pickers in Manolada. In the report, the Ombudsperson questioned the effective functioning of the Labour Inspectorate Department.104 This case was brought before the European Court of Human Rights which found that the applicants' situation was one of human trafficking and forced labour and that Greece had failed in its obligations to prevent the situation of human trafficking, to protect the victims, to conduct an effective investigation into the offences committed and to punish those responsible for the trafficking.105

Thus, with the creation of the aforementioned institutions and extension of the powers of already established institutions such as the Ombudsperson, injured parties, theoretically, have an array of nonjudicial routes they can follow for the purposes of finding redress when discriminated against on the grounds designated by the law. This should contribute to the efficiency and effectiveness of such a process given the cost and slow pace associated with the judicial system.106 However, several problems arise from the current situation vis-a'-vis the related institutions and their powers, as set out by the relevant law, which subsequently affect its actual enforcement and the actual impact it has on combating discrimination in the country. Firstly, only the Ombudsperson is an independent authority with no affiliation to a State institution and, thus, the only body free from any potential governmental influences. In fact, the ECRI has, on several occasions, suggested that, given the importance of such independence, the Ombudsperson's powers be extended so as to allow it to have a more constructive role in the combat of discrimination, enabling it to instigate and participate in cases and to work within the private as well as public domain or, in the event that this is not possible, to establish another independent authority, with more powers, to deal with discrimination.107 Secondly, it could be argued that no adequate redress is essentially provided to injured parties through the nonjudicial route, since only one body has the authority to order the payment of a monetary sum payable to the State rather than in the form of monetary damages to the victim and, since it is the Labour Inspectorate Body that has this authority, such fines can only arise in the sphere of private employment and occupation, Third, the fact that three separate authorities exist that are empowered to deal with the implementation of the law creates a complex situation. For example, the Greek National Commission for Human Rights recommends that all the duties should be transferred to the Ombudsperson, except those in the sphere of access to and provision of goods and services, which should be dealt with by the Commissioner of the Consumer.108 Finally, the activities of the institutions and their actual role in the promotion of equal treatment and effect in tackling the cases of discrimination, as provided for in the directives and the transposing law, are disputed. For example, the Committee of Equal Treatment and the Labour Inspectorate have not yet demonstrated that they are functioning in accordance with the law, with no reported cases to show. The only body that appears to be working in the sphere of its duties under the legislation is the Ombudsperson, with punctual annual reports demonstrating its activities in relation to the pursuance of cases but also in connection with other actions such as awareness-raising in the field of equal treatment. However, as has been pertinently argued, the number of cases received and examined per year, for example, the 139 cases received in 2014 , cannot be deemed to 'reflect the real intensity of 
the phenomenon of discrimination' 109 This is notwithstanding the fact that, as noted above, the number of complaints received is rising due to the victims, such as the Roma, having greater awareness of their rights more generally but also their right to make a complaint to the Ombudsperson. In relation to the number of complaints received by the Ombudsperson and the Equal Treatment Committee, the Economic and Social Council notes that the lack of complaints 'constitutes a worrying phenomenon and does not mean the full implementation of the principle but the lack of knowledge of the relevant rights from the victims and the weakness in tracing such incidents on the part of the relevant bodies'.110 In relation to the Labour Inspectorate Body, the Economic and Social Council underlined that the lack of reported cases dealt with by that body demonstrates the 'inspectors' weakness in tracking down such cases as well as the victim's ignorance of their rights against employers' discriminatory practices'.111

\section{Practical reality.}

In addition to the aforementioned limitations as to the content and application of the law by the relevant judicial and administrative bodies, an array of competent institutions, such as the Economic and Social Council,112 the Greek National Commission for Human Rights and the Ombudsperson, have brought forth the practical examples of Greek daily life which demonstrate that the objectives of the law are not being sought or fulfilled.113 Although the examples below are related to discrimination on the grounds of race and ethnicity as well as religion, this is not to say that discrimination on the other grounds does not occur. For example, in relation to age discrimination, Greece was referred to the European Court of Justice by the European Commission for what it considered to be age discrimination in the field of pension rights in the public service and, more particularly, for diplomats. 114

On the point of the institutions' practical examples, in 2009, the Economic and Social Council put forth certain arguments which are applicable today regarding discrimination. It referred to the vast array of difficulties Roma face in fields such as housing, health and education for purposes of demonstrating that the discrimination of the sort that should be tackled by the directives occurs on a practical level.115 As a result of the practical situation in the framework of discriminatory practices in Greece, the Council argued that the State should reconsider its role as a proactive protector of the groups of persons included in the directives and seek to work on positively and directly supporting the groups affected by discrimination through, inter alia, training competent authorities on non-discrimination and informing vulnerable groups of their rights.116 More particularly, on the part of the executive, there seems to be no actual plan or intention to take constructive steps proactively to combat the discrimination and harassment described in the law and provide for equal treatment through initiatives and measures which meet the spirit of the law.

\section{Conclusion}

In conclusion, the 2000 directives brought about changes to the equal treatment framework of Greece as a result of the passing of Law 3004/2005117 insofar as it simply introduced a theoretically coherent statute to a previously non-existent legal framework. This law applies the minimum standards of the two directives in a non-specific manner, endorsing the limitations, which are the characteristics of the directives themselves. On an enforcement level, the victims of discrimination do not actively pursue their rights, particularly through the courts, 
with many cases of discrimination not being matched by respective complaints to the courts or to equality bodies. In relation to the judiciary, courts have not taken the opportunity to develop and interpret this law whenever possible. Instead, this law seems to be a secondary consideration for a judiciary that has demonstrated, inter alia, slow pace and confusion as to its provisions. Rather than rectifying the enforcement situation to the extent possible, the equality bodies and predominantly the Equal Treatment Committee and the Labour Inspectorate Department do not hit the mark. In short, the failures and shortcomings of the Greek nondiscrimination framework, as described above, are tragically demonstrated in the Manolada case. 118

Notes

1. Council Directive 2000/43/EC of June 29, 2000 on implementing the principle of equal treatment between persons irrespective of racial or ethnic origin.

2. Council Directive 2000/78/EC of November 27, 2000 establishing a general framework for equal treatment in employment and occupation.

3. Mark Bell, "Advancing EU Anti-discrimination Law: The European Commission's 2008 Proposal for a New Directive," The Equal Rights Review 3 (2009): 7.

4. Article 3, Racial Equality Directive.

5. Article 1, Directive on Employment Equality Directive.

6. Bell, “Advancing EU Anti-discrimination Law,” 2009.

7. Ibid.

8. Proposal for a Council Directive on implementing the principle of equal treatment between persons irrespective of religion or belief, disability, age or sexual orientation

9. ENAR Joint press statement: EU equal treatment law: we've been waiting too long: accessed August 25, 2015, http://www.enar-eu.org/Joint-press-statement-EU-equal>

10. Report from the Commission to the European Parliament and the Council: Joint report on the application of Council Directive 2000/43/EC of June 29, 2000 implementing the principle of equal treatment between persons irrespective of racial or ethnic origin (Racial Equality Directive) and of Council Directive 2000/78/EC of November 27, 2000 establishing a general framework for equal treatment in employment and occupation ('Employment Equality Directive') (17.1.2014) COM (2014) 2 final.

11. Athanasios Theodoris, "Report on Measures to Combat Discrimination: Directives 2000/43/ EC and 2000/78/EC, Country Report 2013 - Greece, State of Affairs up to January 1, 2014," European network of legal experts in the non-discrimination field, 8.

12. Nikos Sarris, "The Institutional Framework for Fighting Discrimination," National Centre for Social Research - Institution of Political Sociology, (supported by Progress 2007-2013), 8 . 
13. Nikos Gavalas, "Greek Report on Disability Discrimination Law in the Field of Employment,"2004, http://www.pedz.uni-mannheim.de/daten/edzath/gdem/04/disabfull_el.pdf, 5. Accessed 25 November, 2016.

14. Gavalas, "Greek Report on Disability,” 2004.

15. In the form of Law no. 1414/1984 on the Implementation of the Principle of Gender Equality in Employment Relations repealed by Law 3488/06 (191/A/11.9.08), 'Implementation of the principle of equal treatment between men and women in relation to occupation, vocational training and development, to the terms and conditions of employment and other relevant provisions which was partly repealed by Law 3896/2010 on the Implementation of the principle of equal opportunities and equal treatment between men and women on subjects of employment and occupation'.

16. Sarris, "The Institutional Framework for Fighting Discrimination," 2007-2013.

17. Iyiola Solanke, Making Anti-racial Discrimination Law: A Comparative History of Social Action and Anti-racial Discrimination Law (Routledge, 2009), 77.

18. Christopher McCrudden and Haris Kountouros, in Equality Law for an Enlarged Union understanding the Article 13 Directives, ed. Helen Meenan (Cambridge University Press, 2007), 85 .

19. Theodoris, "Report on Measures to Combat Discrimination," 2014.

20. Article 3, Law 3004/2005.

21. Article 7, Law 3004/2005.

22. ECRI, http://www.coe.int/t/dghl/monitoring/ecri/default_en.asp $>$. Accessed 25 November, 2016.

23. ECRI Report on Greece (fifth monitoring cycle) Published on February 24, 2014, para.18.

24. Article 2, Law 3004/2005.

25. Sarris, "The Institutional Framework for Fighting Discrimination," 19.

26. Dionysis Balourdos and Manolis Chrisakis, Fighting Discrimination: Trends, Challenges and Policies (Papazisi, 2012), Athens, 68.

27. Theodoris, "Report on Measures to Combat Discrimination," 30.

28. Article 7, Law 3004/2006.

29. Case C-303/6. Coleman v. Attridge Law

30. ECRI Report on Greece, para. 21.

31. Theodoris, "Report on Measures to Combat Discrimination," 26.

32. ECRI Report on Greece, paras. 19 and 22.

33. Sarris, "The Institutional Framework for Fighting Discrimination," 16. 
34. Ombudsperson: Special Report on the Fight Against Discrimination (Article 20, para 3 Law 3304/2005), 117.

35. Ombudsperson: Special Report.

36. Ibid, 12.

37. Article 13, Law 3004/2005.

38. Prison Sentence: 6 months to 3 years and monetary fine of 1000 to 5000 euros.

39. This fine is between 500 and 30.000 euros.

40. Article 7 (1) d and e, Law2639/1998.

41. Article 19.3, Law 3004/2005, Karantinos D and Christofilopoulou S, "Network of Socioeconomic Experts in the Anti-discrimination Field," County Report, Greece, National Centre for Social Research, 2009, 19.

42. Karantinos and Christofilopoulou, "Network of Socio-economic Experts," 2009.

43. Article 16 \& 17, Law 3004/2005

44. Karantinos and Christofilopoulou, "Network of Socio-economic Experts," 2009.

45. The objective of the Economic and Social Council is to promote the social dialogue and through it to formulate (if possible) mutually acceptable positions on issues of concern to society as a whole or specific social groups. http://www.oke.gr/oke_cap_en.html. Accessed 25 November, 2016.

46. Article 18 (d), Law 3004/2005.

47. Open Society Foundations: The Race Equality Directive - A Shadow Report, Annex I: Country Summaries, 26, accessed August 21, 2015, https://www.opensocietyfoundations. org/reports/race-equality-directive-shadow-report

48. Theodoris, "Report on Measures to Combat Discrimination," 110.

49. Article 13.3, Law 3004/2005.

50. National Committee for Human Rights, Observations Regarding Law 3004/2005 and Recommendations in Relation to the Need for its Amendment (2010), 16

51 ECRI Report on Greece, para. 24.

52. Law 4310/2014 Research, Technology, innovation and other provisions.

53. Ibid.

54. Article 64.1, Law 4310/2014.

55. Prosecution against doctor (summary), accessed August 23, 2015, http://www.equalitylaw.eu/ index.php? option $1 / 4$ com_edocman\&task $1 / 4$ document.viewdoc\&id $1 / 41406 \& I_{\text {Itemid } 1 / 4295}$

56. Ibid. 
57. Theodoris, "Report on Measures to Combat Discrimination," 110.

58. Justices of the peace of Thessaloniki.

59. More specifically, the 6th Act of the Council of Ministers of 2012, which had been issued in application of the Article 4 of Law 4046/20121 imposed an automatic reduction by $32 \%$ of the minimum wage of young persons under the age of 25.60. Decision no. 34/2015. 61. Decision no. 1624/2012.

62. Theodoris, "Report on Measures to Combat Discrimination," 160.

63. Protocol Number 720 /22-02-2011.

64. Theodoris, "Report on Measures to Combat Discrimination," 59.

65. Ibid.

66. Ibid.

67. Ibid.

68. Ibid.

69. Hellenic League for Human Rights Press Release, accessed August 23, 2015, http://www.hlhr. gr/?MDL1/4pages\&SiteID1/41027

70. Newspaper article (bus driver incident), accessed August 23, 2015, http://www.tovima.gr/ society/article/?aid1/4507428

71. X v. Bank Y, no. 2048/2008.

72. Ibid.

73. Article 20, Law 3004/2005.

74. Article 4.1, Law 3094/2003.

75. Article 4.2, Law 3094/2003.

76. Article 4.6, Law 3094/2003.

77. Article 20.3, Law 3004/2005.

78. Article 4.4, Law 3094/2003.

79. ECRI Report on Greece, para. 31.

80. Article 4.6, Law 3094/2003.

81. Article 4.11, Law 3094/2003.

82. Article 4.10, Law 3094/2003.

83. Ombudsperson: Special Report, 15. http://www.synigoros.gr/?i1/4stp.el.annreports.266957. Accessed 2 December, 2016.

84. Synopsis of Naval case, accessed August 24, 2015, http://www.synigoros.gr/resources/docs/ synoyh-diamesolavhshs-orio-hlikias-_nee_.pdf 
85. Ombudsperson's Diversity Guide for Public Workers, http://www.synigoros.gr/resources/too lip/doc/2014/03/21/web.pdf. Accessed 20 December, 2016.

86. Article 19.2, Law 3004/2004.

87. Article 22 (a) and Article 23, Law 3004/2005.

88. Article 22, Law 3004/2005.

89. Sarris, "The Institutional Framework for Fighting Discrimination," 1.

90. Balourdos and Chrisakis, Fighting Discrimination, 89.

91. The Economic and Social Council promotes social dialogue in Greece, Accessed August 24, 2015, http://www.oke.gr/index_en.html

92. Economic and Social Council, 'Implementing the principle of equal treatment regardless of racial or ethnic origin, religious or other convictions, disability, age or sexual orientation (2009 report) Opinion 223 November 3, 2009, 20.

93. Ibid., 18.

94. Ibid., 19.

95. Article 19.3, Law 3004/2005.

96. The Labour Inspectorate's mandate is to ensure equal treatment in employment. It can award fines of up to 30,000 euros.

97. Economic and Social Council of Greece, "Opinion of the ESC on the Implementation of the Equal Treatment Principle Regardless of Racial or Ethnic Origin, Religious or Other Beliefs, Disability, Age or Sexual Orientation,” (2009), 19.

98. Labour Inspectorate Department Annual Report 2013, accessed August 23, 2010, http://www. Seedd.gr/LinkClick.aspx?fileticket $1 / 41 \mathrm{CDb} 4 \mathrm{fjz} 618 \% 3 D \& \operatorname{tabid}^{1} / 474 \& \mathrm{mid}^{1} / 4446$, 115,81 .

99. Balourdos and Chrisakis, Fighting Discrimination, 88.

100. Newspaper article on acquittal of Manolada perpetrators, accessed August 24, 2015, http:// www.theguardian.com/world/2014/jul/31/greek-court-acquits-farmers-shot-strawberrypickers 101. http://www.gsee.gr/. Accessed 2 January, 2017.

102. Theodoris, "Report on Measures to Combat Discrimination," 48.

103. Ibid.

104. Ombdusperson's Press Release, http://www.synigoros.gr/resources/eggrafo2-2.pdf, 4. Accessed 2 January, 2017.

105. Chowdury and Others v. Greece (ECHR March 3, 2017) Application no. 21884/15.

106. Karantinos and Christofilopoulou, "Network of Socio-economic Experts," 2009.

107. ECRI Report on Greece, para. 31. 
108. Sarris, "The Institutional Framework for Fighting Discrimination,” 20.

109. Antonis Gazakis, Despina Syrri, and Andreas Takis, "Racism and Discrimination in Greece Today," (Heinrich Bo"1l Stiftung, 2014), accessed August 23, 2015, http://gr.boell.org/en/ 2014/10/23/racism-and-discrimination-greece-today, 49.

110. Economic and Social Council of Greece, "Opinion of the ESC on the Implementation," 2009.

111. Economic and Social Council of Greece, "Opinion of the ESC on the Implementation of the Equal Treatment Principle Regardless of Racial or Ethnic Origin, Religious or Other Beliefs, Disability, Age or Sexual Orientation," 2007, 13-14. Available at: http://www.oke.gr/opinion/ op_183.pdf. Accessed on 25 January, 2017.

112. Article 18 provides that the, for purposes of promoting social dialogue the already established Economic and Social Council should, inter alia, compose annual reports on the development of the law under consideration and make recommendations to the government and social partners as to the promotion of equal treatment.

113. Sarris, "The Institutional Framework for Fighting Discrimination,” 19.

114. European Commission Press Release, accessed August 24, 2015, http://europa.eu/rapid/ press-release_MEMO-14-293_en.htm

115. Economic and Social Council of Greece, "Opinion of the ESC on the Implementation," 2009.

116. Ibid., 21-22.

117. Law 3004/2005 on the implementation of the principle of equal treatment irrespective of racial or ethnic origin, religion or other beliefs, disability, age or sexual orientation. Amongst other provisions, this law sets out definitions.

118. This is deemed to be the case both in respect of the actual shootings and of the court decision which came across much criticism. SYRIZA MP V. Katrivanou held that it 'sends the message that a foreign worker can die like a dog in the orchard', accessed August 24, 2015, http://www.theguardian.com/world/2014/jul/31/greek-court- acquits-farmers-shotstrawberrypickers 